\title{
Clair de lune sur la boîte
}

La nuit les feux s'allument

Les rêves aussi.

L'éternel renaît.

Silhouette ivre d'inconsistance

Tu erres dans 1'obscur velouté

Des marchands d'illusions.

Bars, cafés barbares

Falots miroitant dans la pluie

Papillons de nuit indécis

Dansent dans la nuit.

Cris de joie, crits de peine,

Sanglots, râles et soupirs

se mêlent aux ombres

Qui suintent le long des paradis d'une nuit.

Je bois ma solitude

Je fume ma tristesse

$J^{\prime}$ avale mes peines

Et je souris à $1^{\prime}$ ennui.

Les gens dorment

Les choses parlent

Et moi

Je suis.

Mustapha K. Bénouis

The University of Hawaii 